\title{
Weight loss and asthma: a systematic review
}

\author{
I U Eneli, ${ }^{1}$ T Skybo, ${ }^{2}$ C A Camargo $\mathrm{Jr}^{3}$
}

${ }^{1}$ Department of Pediatrics, Ohio State University, Center for Healthy Weight and Nutrition, Columbus Children's Hospital, Columbus, Ohio, USA; ${ }^{2}$ College of Nursing, Mt Carmel School of Nursing, Columbus, Ohio, USA;

${ }^{3}$ Harvard Medical School, Department of Emergency Medicine, Massachusetts General Hospital, Boston, Massachusetts, USA

Correspondence to: Dr I Eneli, Center for Healthy Weight and Nutrition, Columbus Children's Hospital, 118 Timken Hall, 700 Columbus Children's Dr, Columbus, OH 43205, USA; enelii@pediatrics-ohio.state.edu

Received 29 June 2007 Accepted 17 October 2007

\section{ABSTRACT}

Epidemiological studies first demonstrated the association between obesity and asthma and they have begun to provide additional evidence to support causality: a doseeffect relationship, consistency across studies (especially among women) and the correct temporal order (ie, obesity before asthma). To date, relatively few studies have addressed reversibility, an important but less frequently demonstrated epidemiological criterion of causality. Reversibility suggests that if excessive weight is a risk factor for asthma, then reducing body weight should decrease the prevalence of asthma, or at least decrease asthma related symptoms or health care utilisation. We performed a systematic review on weight loss and asthma, based on searches between January 1966 and January 2007 of both PubMed and the Cochrane Clinical Trial Database. Of the 15 relevant studies, asthma was the primary outcome in only five. Only one study was conducted in children. Regardless of the type of intervention (surgical vs medical), all 15 studies noted an improvement in at least one asthma outcome after weight loss. The improvement was noted across studies that differed in sample age, gender or country of origin. The heterogeneity of the interventions and outcomes precluded quantitative synthesis. We briefly review the role of specific factors (eg, gastro-oesophageal reflux) in the weight loss-asthma association, and potential directions for future research.

Rising obesity prevalence rates are a concern worldwide. Between 1980 and 2000, obesity rates in the USA increased by $50 \%$ for adults and threefold for children and adolescents. ${ }^{12}$ Over a similar timeframe, asthma prevalence rose by 73\%. ${ }^{3}{ }^{4}$ Although the upward trends transcend age, sex, race/ethnicity and geographic location, they disproportionately affect minority groups, the socioeconomically disadvantaged and inner city populations.

The simultaneous rise in the frequency of both conditions may not be coincidental. The 1999 reports of a strong positive association between body mass index (BMI) and risk of adult onset asthma in both the Nurses' Health Study ${ }^{5}$ and the 1970 British Cohort Study ${ }^{6}$ prompted widespread interest in the obesity-asthma hypothesis. Increased BMI has also been associated with increased severity of asthma symptoms and use of health services. ${ }^{7}$ Although several groups around the world have confirmed a positive association between obesity and both prevalent and incident asthma, ${ }^{89}$ other researchers have shown the increase in asthma prevalence to be independent of rising obesity rates. ${ }^{10}{ }^{11}$ In a British study, ${ }^{11}$ the odds ratio per year for asthma between 1982 and 1994 remained unchanged when adjusted for BMI, suggesting the obesity-asthma link may not be causal but rather reflect the effect of recent lifestyle changes. Whether a causal relationship truly exists, the potential for reverse causality (ie, asthma causes obesity), and the biological mechanisms for the association, remain active topics of discussion. ${ }^{9}{ }^{12-14}$

Cohort studies provide the strongest epidemiological evidence that obesity is a risk factor for asthma by demonstrating not only a significant relationship with incident asthma but also the correct temporal order. ${ }^{5681516}$ In our initial prospective study of 85911 female registered nurses, weight gain greater than $25 \mathrm{~kg}$ after the age of 18 years was associated with an almost fivefold likelihood (odds ratio (OR) 4.7, 95\% confidence interval (CI) 3.1 to 7.0 ) of reporting a doctor diagnosis of adult onset asthma. ${ }^{5}$ Proposed mechanisms for the obesity-asthma link include gastro-oesophageal reflux (GOR), genetic factors, dietary intake, inflammatory mediators (eg, interleukins), abnormal chest wall mechanics and physical activity, but the evidence has not been consistent across studies. ${ }^{13}$

Some studies have investigated the obesityasthma link from a different perspective, hypothesising that if excessive weight is the risk factor, then reducing body weight should decrease the prevalence of asthma, or at least reduce asthma related symptoms or health care utilisation. If true, this would provide evidence of reversibility, an important epidemiological criterion of causality. ${ }^{17}$ Unfortunately, most of these studies are small, underpowered and rarely focus on asthma as the only outcome. In light of these limitations, a systematic review on weight loss and asthma would be timely, and the results, taken together, might contribute important insights to current discussion about the obesity-asthma association. A systematic review would also enable us to generate hypotheses for future research on the factors (eg, GOR) that are most likely to mediate or modify the obesity-asthma link. Accordingly, this systematic review will conduct an indepth evaluation of the extant literature on weight loss and asthma and examine potential directions for future research.

\section{METHODS AND MATERIALS}

We performed a computerised search of PubMed and the Cochrane Clinical Trial Database between January 1966 and January 2007 using the following combination of search terms: "weight loss/asthma, bariatric surgery/asthma, gastric bypass/asthma, physical activity or exercise/asthma, and diet/ weight loss/asthma". To broaden our coverage of the literature, we also reviewed bibliographies of textbooks, original research, symposia and commentaries for additional references. We used the 
following a priori inclusion criteria: (a) asthma as an outcome measure and (b) studies on weight loss. Two authors (IUE and CAC) reviewed each abstract. We excluded case studies, reviews ${ }^{9-14} 18$ and publications where the outcome was limited to only pulmonary function indices as these did not represent a diagnosis of asthma. ${ }^{19-25}$ We did not identify any relevant case studies. Fifteen of 21 papers met all of the inclusion criteria and were selected for critical review.

Next, two authors (IUE and TS) reviewed each paper, extracting information on study design, sample size, population, method of weight loss, identification of covariates, asthma diagnosis and outcomes. We categorised outcomes into number of asthma exacerbations, asthma symptoms, impact of asthma on daily function, use of asthma medications and asthma related health care utilisation (eg, emergency department visits, hospitalisations). Based on method of weight loss, studies were divided into two categories: surgical and medical weight loss interventions.

\section{STUDIES ON WEIGHT LOSS AND ASTHMA}

Of the 15 studies that addressed weight loss and asthma (table 1), asthma was the primary outcome in only five studies. ${ }^{19}$ 26-29 More often, asthma related outcomes were included in a list of outcomes from different clinical conditions (eg, percentage weight loss, type 2 diabetes, sleep apnoea, hypertension, dyslipidaemia). The method of asthma diagnosis was usually not described. The median sample size for the asthma subpopulation in the included papers was 28 subjects (range 6-40), with median length of follow-up of 1 year (range 8 weeks to 14 years). All of the studies were conducted in adults (mostly women) and in white populations, which limits the generalisability of the findings to men and other racial/ethnic groups. There was a single paediatric study, with a single subject with asthma. ${ }^{30}$ Only four studies used low calorie diets or a medical weight loss programme. ${ }^{192728} 31$ The most common surgical procedure was the vertical banded gastroplasty or Lap band procedure which was used in seven studies. ${ }^{26}{ }^{32-38}$ The majority of the studies reported at least one of the following outcomes: use of asthma medication, severity of asthma symptoms and resolution of asthma symptoms (yes/no). The most frequently assessed outcome was resolution of asthma symptoms. None of the studies investigated healthcare costs related to office visits, urgent or emergent care, missed workdays or years of productive life lost. Despite similar outcome measures in most of the studies, the heterogeneity of the study populations, interventions and definition of outcomes precluded quantitative analysis. Improvement in asthma outcomes was seen across studies that differed in sample age, gender or country of origin.

One of the earlier studies to focus on asthma outcomes was conducted by Dixon et al in 1999. ${ }^{33}$ Asthma was assessed preoperatively and at least 12 months after surgery using a scaled asthma score based on severity, daily impact, medications needed, hospitalisation, sleep and exercise. Patients were categorised into mild, moderate or severe asthma based on the National Asthma Campaign criteria. ${ }^{40}$ Although 10 had a history of severe asthma at baseline, none had severe asthma at the 12 month follow-up. The impact of asthma on daily living activities improved by $50 \%$. There was a $57 \%$ decline in the number of patients that needed daily medications from 14 to six after weight loss. The mean preoperative scaled asthma score of 44.5 (16) decreased to 14.3 (11) at follow-up ( $p<0.001)$. The investigators reported a correlation coefficient of 0.21 between per cent weight loss and improvement in asthma scores.

In another study of 24 patients with asthma who had laparoscopic adjustable gastric banding, use of asthma medication declined for 10 patients and was completely discontinued for four. None of the patients noted an increase in asthma symptoms or medication use, although there was no significant change in their reported asthma related quality of life pre- and postoperatively. ${ }^{32}$ Stenius-Aarniala et al conducted a randomised controlled trial using low calorie diets in Finland. ${ }^{27}$ Each participant completed a dyspnoea scale using a visual analogue scale from 0 to $100 \mathrm{~mm}$. Health status related to asthma was measured using three domains: respiratory symptoms; limitation in physical activity; and social and psychological impact. Improved health status was defined as a decline in the total score percentage for all three domains. Following the intervention, there was a fall in reported dyspnoea scale by 12 units for the intervention group compared with 1 unit for controls $(p=0.03)$, while the health status scale decreased by $10(95 \%$ CI -1 to -18$)$. Although the authors reported a statistically significant difference in the use of rescue medication between the two groups $(0.5$ doses for the treatment group and no change for the control group), the difference probably would not have been meaningful in clinical practice. Only one study ${ }^{36}$ has indirectly examined asthma expenses before and after weight loss, using a population based study. At the 6 year follow-up, the 510 participants that underwent a surgical procedure had a $20 \%$ relative decrease in weight compared with the medical weight loss group $(n=455)$ that had lost less than $5 \%$. Pharmaceutical costs for asthma in the surgical group decreased from 213 to 164 Swedish kroner while for the medical group the costs increased from 127 to 165 Swedish kroners.

Macgregor and Greenberg in Australia ${ }^{26}$ described strong evidence of reversibility in their weight loss study. In a subset of five patients with asthma who had bariatic surgery, asthma symptoms improved following weight loss. The symptoms worsened after subjects regained some of their weight. Subsequently, the five patients underwent revisional surgery, lost weight again and the frequency of asthma symptoms decreased again. In the single patient in the study who did not lose weight despite surgery, the frequency of his asthma symptoms remained unchanged.

Two studies ${ }^{26}{ }^{38}$ assessed for GOR, a condition which may mediate or confound an association between weight loss and change in asthma status. In the study by Macgregor and Greenberg, ${ }^{26}$ complete remission of asthma occurred in $48 \%$, with an additional $12.5 \%$ free of asthma exacerbations. Mean excess weight loss following surgery was $68 \%$. Improvement of asthma symptoms was marked among subjects who had severe attacks (ie, those with $>10$ exacerbations in 1 year). Of the 36 subjects whose asthma improved following weight loss and who reported acid reflux symptoms preoperatively, $50 \%$ had complete resolution of their reflux postoperatively. Although the authors reported a significant correlation between weight loss and asthma symptoms, they did not find a statistically significant association between change in GOR and change in asthma. Spivak and colleagues ${ }^{38}$ reported similar findings in 48 patients who had a diagnosis of GOR prior to surgery. In their study, the GOR of seven patients $(15 \%)$ improved after weight loss (mean excess weight loss of $45 \%$ ) while for 35 patients (73\%) GOR resolved completely.

In summary, all studies, regardless of mode of intervention for weight loss, reported an improvement in some measure of asthma status. Although these studies are hardly definitive, the 
Table 1 Studies on weight loss and asthma

\begin{tabular}{|c|c|c|c|c|c|}
\hline Study & Subject & Asthma diagnosis* & Intervention & Duration & Resolves at follow-up \\
\hline \multicolumn{6}{|l|}{ Surgical interventions } \\
\hline Ahroni $^{32} 2005$ USA & $\begin{array}{l}\text { Total }=179 \\
\text { Age } 19-70(\chi=44) \\
\text { Mean BMI } 46 \mathrm{~kg} / \mathrm{m}^{2} \\
\text { Asthma } \mathrm{n}=24(13.4 \%)\end{array}$ & History of asthma & LAGB & $1 \mathrm{y}$ & $\begin{array}{l}\text { Mean BMI } 32.3(7.0) \mathrm{kg} / \mathrm{m}^{2}(\downarrow 18.5) ; \downarrow \text { in use of } \\
\text { asthma meds }(30 \%) ; \text { asthma much better }(74 \%) ; \\
\text { no change in SF-36 (quality of life) }\end{array}$ \\
\hline Dhabuwala $^{39} 2000$ New Zealand & $\begin{array}{l}\text { Total }=157 ; 80 \% \text { female } \\
\text { Age } 15-62(\chi=41) \\
\text { Mean BMI } 45 \mathrm{~kg} / \mathrm{m}^{2} \\
\text { Asthma } \mathrm{n}=34(21.7 \%)\end{array}$ & $\begin{array}{l}\text { History of asthma } \\
\text { Use of meds }\end{array}$ & SRGBP & $\begin{array}{l}2.5 y \\
(0-9.5)\end{array}$ & $\begin{array}{l}\text { BMI } 28 \mathrm{~kg} / \mathrm{m}^{2}(20-52) \text {; asthma resolved }-50 \% \text {; } \\
\text { improved-26\%, unchanged-14\%; reduced } \\
\text { medication use }(84 \%)\end{array}$ \\
\hline Dixon $^{33} 1999$ Australia & $\begin{array}{l}\text { Total }=380 ; 88 \% \text { female } \\
\text { Age } 17-69 \text { (median 39) } \\
\text { Mean BMl } 46 \mathrm{~kg} / \mathrm{m}^{2} \\
\text { Asthma } \mathrm{n}=32(8.4 \%)\end{array}$ & Physician diagnosis & LAGB & $12 \mathrm{mo}$ & $\begin{array}{l}\text { BMI } 32.9 \mathrm{~kg} / \mathrm{m}^{2} \text {; asthma score } 14.3(\downarrow 30.2 \\
\text { points), asthma severity score } 2.03(\downarrow 1.63 \\
\text { points); daily impact score } 1.21(\downarrow .87 \text { points); } \\
\downarrow \text { use of daily meds }(81 \%) \text {, no hospitalisation, } 34 \% \\
\text { resolved symptoms }\end{array}$ \\
\hline $\mathrm{Hall}^{34} 1990$ Australia & $\begin{array}{l}\text { Total }=310 ; 93 \% \text { female } \\
\text { Age } 28-40 \text { (median } 34) \\
\text { Wt range } 110-115 \mathrm{~kg} \\
\text { Asthma } \mathrm{n}=12(3.9 \%)\end{array}$ & $\begin{array}{l}\text { History of asthma } \\
\text { Use of meds }\end{array}$ & $\begin{array}{l}\text { VBGP } \\
\text { Gastric bypass }\end{array}$ & $3 y$ & $\begin{array}{l}\text { Wt }(\mathrm{kg}) \text { median } 76-93 ; \text { discontinued asthma meds } \\
(50 \%)\end{array}$ \\
\hline Macgregor $^{26} 1993$ USA & $\begin{array}{l}\text { Total }=40 ; 80 \% \text { female } \\
\text { Age 23-68; mean BMl } 46 \\
\text { Asthma } n=40(100 \%)\end{array}$ & $\begin{array}{l}\text { History of asthma } \\
\text { Use of meds } \\
\text { Frequency of attacks }\end{array}$ & $\begin{array}{l}\text { VBGP } \\
\text { Gastric bypass }\end{array}$ & $\begin{array}{l}2-11 \\
(\chi=4) y\end{array}$ & $\begin{array}{l}\text { BMI } 30 \text { at } 4 \text { y; } 90 \% \text { improved asthma symptoms; } \\
48 \% \text { remission, discontinued meds: moderate } \\
(42 \%) \text {; severe }(36 \%)\end{array}$ \\
\hline Murr $^{35} 1995$ USA & $\begin{array}{l}\text { Total }=62 ; 80 \% \text { female } \\
\text { Age } 50-71(\chi=57) \\
\text { Mean wt } 125(4) \mathrm{kg} \\
\text { Asthma } \mathrm{n}=6(9.6 \%)\end{array}$ & $\begin{array}{l}\text { History of asthma } \\
\text { Use of meds }\end{array}$ & $\begin{array}{l}\text { VBGP } \\
\text { Gastric bypass } \\
\text { BPD-DS }\end{array}$ & $1-3 y$ & $\begin{array}{l}\text { Wt loss } 44(5) \% \text { at } 1 \mathrm{y} \text {; wt loss } 33(6) \% \text { at } 3 \mathrm{y} \text {; } \\
\text { decreased use of asthma meds }(100 \%)\end{array}$ \\
\hline Narbro $^{36} 2002$ Sweden & $\begin{array}{l}\text { Total }=1294 ; 69 \% \text { female } \\
\text { Age } 37-60(\chi=48) \\
\text { Mean BMI } 41 \mathrm{~kg} / \mathrm{m}^{2} \\
\text { Asthma } \mathrm{n}=\text { not reported }\end{array}$ & $\begin{array}{l}\text { History of asthma } \\
\text { Use of meds }\end{array}$ & $\begin{array}{l}\text { Gastric banding } \\
\text { Gastric bypass } \\
\text { VBGP }\end{array}$ & $6 y$ & $\begin{array}{l}\downarrow \text { Weight } 16 \% \text {; no difference in cost of asthma } \\
\text { meds between both the intervention group and } \\
\text { reference group at follow-up }\end{array}$ \\
\hline 0’Brien ${ }^{37} 2002$ Australia & $\begin{array}{l}\text { Total }=709 ; 85 \% \text { female } \\
\text { Median age } 41(16-71) \\
\text { Mean BMI } 45(7) \mathrm{kg} / \mathrm{m}^{2} \\
\text { Asthma } \mathrm{n}=33(4.6 \%)\end{array}$ & $\begin{array}{l}\text { Asthma severity score } \\
\text { Use of meds }\end{array}$ & LAGB & $1 \mathrm{y}$ & $\begin{array}{l}\text { Mean BMI } 31 \mathrm{~kg} / \mathrm{m}^{2} \text {; asthma resolved }(30 \%) \text {; no } \\
\text { hospitalisations; discontinued asthma meds }(60 \%) \text {; } \\
\text { no oral steroids needed }\end{array}$ \\
\hline Simard $^{29} 2004$ Canada & $\begin{array}{l}\text { Total }=398 ; 70 \% \text { female } \\
\text { Age } 22-67 \text { (mean } 45) \\
\text { Mean BMI } 50 \mathrm{~kg} / \mathrm{m}^{2} \\
\text { Asthma } \mathrm{n}=34(9 \%)\end{array}$ & $\begin{array}{l}\text { History of asthma } \\
\text { Use of meds }\end{array}$ & BPD-DS & $2 y$ & $\begin{array}{l}\text { Of the } 139 \text { at follow-up: BMI } 30 \mathrm{~kg} / \mathrm{m}^{2} \text {; improved } \\
\text { severity of asthma ( } 79 \%)\end{array}$ \\
\hline Spivak $^{38} 2005$ USA & $\begin{array}{l}\text { Total }=163 ; 90 \% \text { female } \\
\text { Age } 18-63 \text { (mean } 42) \\
\text { Mean BMI } 45 \mathrm{~kg} / \mathrm{m}^{2} \\
\text { Asthma } \mathrm{n}=11(6.7 \%)\end{array}$ & $\begin{array}{l}\text { History of asthma } \\
\text { Use of meds }\end{array}$ & Lap band & $3 y$ & Mean BMI $35\left(\downarrow 10 \mathrm{~kg} / \mathrm{m}^{2}\right) ; 82 \%$ resolved asthma \\
\hline \multicolumn{6}{|l|}{ Medical interventions } \\
\hline Sugerman $^{30} 2003$ USA & $\begin{array}{l}\text { Total }=33 \\
\text { Asthma } \mathrm{n}=1(3.3 \%) \\
\text { Mean age } 16(12-18) \\
\text { Mean BMI } 52 \mathrm{~kg} / \mathrm{m}^{2}\end{array}$ & History of asthma & Gastric bypass & Up to $14 \mathrm{y}$ & Asthma resolved (100\%) \\
\hline Aaron $^{31} 2004$ Canada & $\begin{array}{l}\text { Total }=58 ; 100 \% \text { female } \\
\text { Age } 44(13) \\
\text { Mean wt } 115(26) \mathrm{kg} \\
\text { Asthma } \mathrm{n}=24(41 \%)\end{array}$ & Physician diagnosis & Wt loss programme & $6 \mathrm{mo}$ & $\begin{array}{l}\text { Mean wt } \downarrow 20 \mathrm{~kg}(19 \%) \text {; for } 10 \% \text { wt loss, FVC } \\
\uparrow 92 \mathrm{ml} \text {; for } 10 \% \text { wt loss, FEV } \uparrow 73 \mathrm{ml} \text {; } \\
\text { improvement in symptoms }(\mathrm{p}<0.05) \text {; no } \\
\text { hospitalisations or ER visits }\end{array}$ \\
\hline Hakala $^{19} 2000$ Finland & $\begin{array}{l}\text { Total }=14 ; 80 \% \text { female } \\
\text { Age } 25-62 \\
\text { Mean BMI } 37(33-43) \\
\text { Asthma } n=14(100 \%)\end{array}$ & Physician diagnosis & Low cal diet & $8 w k$ & $\begin{array}{l}\text { BMI } 32.1 \mathrm{~kg} / \mathrm{m}^{2}\left(\downarrow 5.1 \mathrm{~kg} / \mathrm{m}^{2}\right) \text {; dyspnoea score } \\
8.1(\downarrow 6.5) ; \text { use of rescue meds } 0.4 \text { does/day } \\
(\downarrow 0.2)\end{array}$ \\
\hline Johnson ${ }^{28} 2007$ USA & $\begin{array}{l}\text { Total }=10,80 \% \text { female } \\
\text { Age adult } \\
\text { Mean wt } 104.9 \mathrm{~kg} \\
\text { Asthma } \mathrm{n}=10(100 \%)\end{array}$ & Physician diagnosis & Low cal diet & $8 w k$ & $\begin{array}{l}\text { Weight } 96.4 \mathrm{~kg}(\downarrow 8 \%) \text {; improved asthma control } \\
\text { on ACO }\end{array}$ \\
\hline
\end{tabular}


Table 1 Continued

\begin{tabular}{|c|c|c|c|c|c|}
\hline Study & Subject & Asthma diagnosis* & Intervention & Duration & Resolves at follow-up \\
\hline Stenius-Aarniala ${ }^{27} 2000$ Finland & $\begin{array}{l}\text { Total }=38 \\
\text { Age } 18-60 \\
\text { BMI } 30-42 \mathrm{~kg} / \mathrm{m}^{2} \\
\text { Asthma } 38(100 \%)\end{array}$ & Physician diagnosis & $\begin{array}{l}\text { Low cal diet for } \\
8 \text { weeks }\end{array}$ & $1 \mathrm{y}$ & $\begin{array}{l}\text { Mean wt: treatment grp } \downarrow 11 \mathrm{~kg}(11 \%) \text {, control } \\
\text { grp } 0.3 \% \text {; median No of exacerbations: treatment } \\
\text { group } 1(0-4) \text {, control grp } 1(0-7) \text {; median No of } \\
\text { oral steroids courses: treatment group } 1(0-3) \text {, } \\
\text { control grp } 2 \text { ( } 0-3)\end{array}$ \\
\hline
\end{tabular}

*History of asthma denotes subject was identified as an individual with asthma.

ACQ, Juniper Asthma Control Questionnaire; BMI, body mass index; BPD-DS, biliopancreatic diversion with duodenal switch; FEV, forced expiratory volume; FVC, forced vital capacity; LAGB, laparoscopic adjustable gastric banding; PEF, peak expiratory flow; PFT, pulmonary function tests; SEK, Swedish Kroners; SRGBP, silastic ring gastric bypass; VBGP, vertical banded gastroplasty.

consistency of the results is reassuring and they provide some evidence to support a causal relationship between obesity and asthma. The mechanism to explain these observations merits further investigation.

\section{POTENTIAL MECHANISMS FOR IMPROVED ASTHMA STATUS}

In this section, we briefly review variables that may mediate or confound the association between weight loss and improved asthma (box 1). Understanding or refuting each pathway requires a better understanding of the variables that may be involved in the weight loss-asthma link.

\section{Gastro-oesophageal reflux}

Weight loss improves both GOR and asthma symptoms, a situation that suggests that GOR may mediate or modify the obesity-asthma link. ${ }^{41-43}$ The relationship between GORDasthma is thought to be bidirectional. Asthma increases intraabdominal pressure while asthma medications such as xanthine derivatives and systemic $\beta_{2}$ adrenergic agonists decrease lower oesophageal sphincter tone, ${ }^{41}$ predisposing to GOR. GOR is an exacerbating factor in asthma. Proposed mechanisms include: (1) chest expansion with diaphragmatic flattening, which leads to air trapping and negative intrathoracic pressure, and thereby impairs the integrity of the lower gastro-oesophageal sphincter; and (2) gastric acid within the oesophagus initiates a vagal response causing a bronchospastic reflex within the airways. While some studies demonstrate an increased rate of GOR with obesity, ${ }^{42}{ }^{43}$ others do not find this association. ${ }^{44}$ A meta-analysis found a dose effect, with increasing reflux associated with overweight (OR 1.57, 95\% CI 1.36 to 1.80) and obesity (OR $2.15,95 \%$ CI 1.89 to 2.45$).^{42}$

One of the strongest pieces of evidence that BMI and GOR are connected stems from the improvement in GOR symptoms after weight loss. ${ }^{26}{ }^{38}$ In a prospective follow-up study (19 months (range 7-32)) of 31 patients who had undergone gastric banding, patients reported a decrease in symptoms from $48 \%$ preoperatively to $16 \%$ postoperatively $(p=0.01)$ and the diagnosis of GOR on $24 \mathrm{~h} p \mathrm{H}$ recordings decreased from $77 \%$ to $37 \%(p=0.01) .{ }^{45}$ Both of the studies in our review that investigated the role of GOR in the asthma-obesity link were

Box 1 Proposed variables in the asthma and weight loss relationship

Mediators or confounders

- Gastro-oesophageal reflux

- Inflammatory mediators (eg, leptin, interferon, interleukins)

- Dietary intake

- Chest wall mechanics

- Physical activity underpowered. $^{26}{ }^{37}$ A well designed large prospective cohort study is needed to confirm or refute the hypothesis that GOR mediates or at least contributes to the association between BMI and asthma.

\section{Dietary intake}

The link between dietary content, obesity and asthma-should one exist-is undoubtedly complex. Cross sectional studies have suggested a deleterious role for linoleic acid and other fatty acids and asthma. ${ }^{46-51}$ Linoleic acid, an essential fatty acid, has been implicated in the production pathway of several prostanoids and leukotrienes active in bronchoconstriction and neutrophil chemotaxis. ${ }^{52}$ By contrast, omega-3 polyunsaturated fatty acids (n-3 PUFA) which uses linolenic acid as its building block competes with arachidonic acid to form less active metabolites, and may thereby reduce airway inflammation and bronchoconstriction. ${ }^{53}{ }^{54}$ Oddy et al reported cross sectional data showing a positive association between dietary n-6:n-3 fatty acid ratio and asthma in children, ${ }^{55}$ while a long term double blind trial of $n-3$ PUFA supplementation in patients with asthma found a positive effect on respiratory function. ${ }^{56}$ But more recent research disputes the "fatty acid" theory of asthma. ${ }^{57} 58$ In a 2005 study, Nagel and Linseisen found no association between fat intake, saturated fatty acids, monosaturated fatty acids or n6/n3 PUFA ratio and asthma, or between BMI and asthma. ${ }^{58}$

\section{Inflammatory mediators}

Interleukin (IL) 6, expressed by adipocytes, has been associated with IL4, IL2 and tumour necrosis factor stimulation and other cytokines implicated in asthma. Leptin, a protein secreted by fat cells and found in greater amounts in obese individuals, has also been associated with higher interleukin levels in individuals with asthma. ${ }^{59}{ }^{60}$ In a study of overweight 12 year olds, who had been born with a very low birthweight, leptin levels were considerably higher in those with current asthma compared with overweight children without asthma (median value $30.8 \mathrm{vs}$ $14.3 \mathrm{ng} / \mathrm{ml}) .{ }^{60}$ Using data from the National Health and Nutrition Examination Survey, Sood and colleagues ${ }^{59}$ found higher leptin levels among participants with asthma compared with those who did not have asthma (geometric mean (SE) 9.2 (0.6) $\mu \mathrm{g} / \mathrm{l}$ vs $7.6(0.2) \mu \mathrm{g} / \mathrm{l} ; \mathrm{p}=0.02)$. The association was stronger among females, especially premenopausal women. However, in a regression analysis, leptin levels did not explain the association between BMI and asthma noted in the study population.

\section{Chest mechanics and physical activity}

In a recent systematic review, Lucas and Platts-Mills described five prospective studies in adults and children that reported a relationship between decreased physical activity and asthma, ${ }^{12}$ suggesting decreased physical activity precedes asthma. 
Likewise, in the European Community Respiratory Health Survey II, participants who exercised for $4 \mathrm{~h}$ or more/day had a lower prevalence of bronchial hyperresponsiveness compared with those who exercised for less than $1 \mathrm{~h}$ (15.9\% vs $10.7 \%){ }^{61}$ Dysfunctional chest wall mechanics, due to extrinsic chest wall and intra-abdominal adipose tissue, are hypothesised to prevent full downward excursion during deep inspiration with a resulting decrease in forced expiratory volume in $1 \mathrm{~s}$, forced vital capacity and total lung capacity, and a set-up for development of the latch phase. ${ }^{13}$ This state is thought to lead to sustained airway obstruction with increased airway hyperresponsiveness. During physical activity, deeper breaths are taken which increase end tidal volume, avoiding the latch phase. Another mechanism by which physical activity may exert its influence may be through an inflammatory pathway. Participation in physical activity has been linked to lower high sensitivity $C$ reactive protein levels, ${ }^{62}$ although not consistently. ${ }^{63}$ This effect was stronger among individuals who engage in vigorous activity compared with moderate and light activity, suggesting a dose effect.

\section{DISCUSSION}

As with most systematic reviews, our findings are limited by the quality and quantity of information provided in the primary studies. The heterogenity of the study outcomes and interventions precluded a quantitative synthesis. Nonetheless, there was a consistent improvement in asthma outcomes (symptoms, use of medications or hospitalisations) across all studies. Asthma was typically determined by self-report and use of asthma medications, which might not truly reflect a diagnosis of asthma. Symptoms such as cough or shortness of breath occur in a wide variety of conditions, which can be inadvertently misdiagnosed as asthma. Poor physical conditioning with activity seen in overweight individuals can also be misdiagnosed as asthma or an asthma exacerbation.

Subjects represented a large age range, from young adults to older adults in their 60s. There was, however, only one adolescent subject. The paucity of data on weight loss and childhood asthma is a limitation that requires attention. It will be important to demonstrate that weight loss improves asthma in children, especially as the natural history of asthma during childhood differs from that with adult onset. ${ }^{64}$ Assessing asthma severity according to established guidelines such as the National Asthma Campaign criteria ${ }^{40}$ or the National Institutes of Health asthma guidelines ${ }^{64}{ }^{65}$ would provide a better baseline asthma status with which to compare subjects later in the course of the weight loss study. With most of the studies in our review, asthma was the not the primary outcome, perhaps reducing the chance that the results were skewed in favour of a publication bias. However, publication bias still poses a real threat as studies reporting a positive association are more likely to be published.

\section{Conclusions}

Despite a relatively small extant literature, and several methodological limitations, our systematic review found a fairly consistent association between weight loss and improved asthma. The interventional nature of the reviewed studies suggest causality with obesity as the risk factor. Nevertheless, small sample sizes and inconsistent methods make aetiological interpretation challenging. Most of the studies were observational or quasi-experimental, making it difficult to account adequately for some factors that can confound or modify the association (eg, severity of asthma, presence or absence of gastro-oesophageal reflux). Randomised clinical trials with weight loss intervention in an established asthma cohort will allow us to better assess the effect of weight loss per se. The intervention can target nutrients that have been tested in both asthma and obesity trials (eg, polyunsaturated fatty acids). ${ }^{56} 66-68$ As with any weight loss trial, the challenge is selecting an effective intervention, ensuring participant compliance and limiting attrition. Investigators will need to recognise that loss to follow-up may be differential, with patients with severe asthma dropping out if they feel they will be unable to comply with the certain aspects of the intervention (eg, physical activity).

We hope that this review will motivate further work on this important topic. Future randomised trials, with an emphasis on elucidating biological mechanisms, will further clarify the nature of the association between weight loss and asthma. Finally, identification of an effective weight loss strategy for obese patients with asthma would reduce the medical, social and economic burden of both health conditions for the individual and general population.

Competing interests: None.

\section{REFERENCES}

1. Ogden CL, Carroll MD, Curtin LR, et al. Prevalence of overweight and obesity in the United States, 1999-2004. JAMA 2006;295:1549-55.

2. Flegal KM, Carroll MD, Kuczmarski RJ, et al. Overweight and obesity in the United States: prevalence and trends, 1960-1994. Int J Obes Relat Metab Disord 1998;22:39-47.

3. Mannino DM, Homa DM, Akinbami LJ, et al. Surveillance for asthma-United States, 1980-1999. MMWR Surveill Summ 2002;51:1-13.

4. National Center for Health Statistics. Asthma prevalence, health care use and mortality, 2002. Centers for Disease Control and Prevention. 2002. Available at http:// www.cdc.gov/nchs/products/pubs/pubd/hestats/asthma/asthma.htm laccessed 26 March 2008).

5. Camargo CA Jr, Weiss ST, Zhang S, et al. Prospective study of body mass index, weight change, and risk of adult-onset asthma in women. Arch Intern Med 1999:159:2582-8.

6. Shaheen SO, Sterne JA, Montgomery SM, et al. Birth weight, body mass index and asthma in young adults. Thorax 1999;54:396-402.

7. Belamarich PF, Luder E, Kattan M, et al. Do obese inner-city children with asthma have more symptoms than nonobese children with asthma? Pediatrics 2000; 106:1436-41.

8. Beuther DA, Sutherland ER. Overweight, obesity, and incident asthma: a metaanalysis of prospective epidemiologic studies. Am J Respir Crit Care Med 2007;175:661-6.

9. Ford ES. The epidemiology of obesity and asthma. J Allergy Clin Immunol 2005;115:897-909.

10. Braback L, Hjern A, Rasmussen F. Body mass index, asthma and allergic rhinoconjunctivitis in Swedish conscripts - a national cohort study over three decades. Respir Med 2005;99:1010-14.

11. Chinn S, Rona RJ. Can the increase in body mass index explain the rising trend in asthma in children? Thorax 2001;56:845-50.

12. Lucas SR, Platts-Mills TAE. Paediatric asthma and obesity. Paediatr Respir Rev 2006; 7:233-8.

13. Tantisira KG, Weiss ST. Complex interactions in complex traits: obesity and asthma Thorax 2001;56(Suppl 2):ii64-73.

14. Chinn S. Obesity and asthma. Paediatr Respir Rev 2006;7:223-8.

15. Romieu I, Avenel V, Leynaert B, et al. Body mass index, change in body silhouette, and risk of asthma in the E3N cohort study. Am J Epidemiol 2003;158:165-74.

16. Mannino DM, Mott J, Ferdinands JM, et al. Boys with high body masses have an increased risk of developing asthma: findings from the National Longitudinal Survey of Youth (NLSY). Int J Obes (Lond) 2006;30:6-13.

17. Hill $\mathbf{A B}$. The environment and disease: Association or causation? Proc $R$ Soc Med Lond 1965:58:295-300.

18. Shore SA. Obesity and asthma: implications for treatment. Curr Opin Pulm Med 2007:13:56-62.

19. Hakala K, Stenius-Aarniala B, Sovijarvi A. Effects of weight loss on peak flow variability, airways obstruction, and lung volumes in obese patients with asthma. Chest 2000;118:1315-21.

20. Santana AN, Souza R, Martins AP, et al. The effect of massive weight loss on pulmonary function of morbid obese patients. Respir Med 2006;100:1100-4.

21. Stalnecker MC, Suratt PM, Chandler JG. Changes in respiratory function following small bowel bypass for obesity. Surgery 1980;87:645-51.

22. De Lorenzo A, Maiolo C, Mohamed El, et al. Body composition analysis and changes in airways function in obese adults after hypocaloric diet. Chest 2001;119:1409-15. 
23. Wadstrom C, Muller-Suur R, Backman L. Influence of excessive weight loss on respiratory function. A study of obese patients following gastroplasty. Eur J Surg 1991;157:341-6.

24. Davila-Cervantes A, Dominguez-Cherit G, Borunda D, et al. Impact of surgicallyinduced weight loss on respiratory function: a prospective analysis. Obes Surg 2004;14:1389-92.

25. El-Gamal H, Khayat A, Shikora S, et al. Relationship of dyspnea to respiratory drive and pulmonary function tests in obese patients before and after weight loss. Chest 2005; 128:3870-4.

26. Macgregor AM, Greenberg RA. Effect of surgically induced weight loss on asthma in the morbidly obese. Obes Surg 1993;3:15-21.

27. Stenius-Aarniala B, Poussa T, Kvarnstrom J, et al. Immediate and long term effects of weight reduction in obese people with asthma: randomised controlled study. BMJ 2000;320:827-32.

28. Johnson JB, Summer W, Cutler RG, et al. Alternate day calorie restriction improves clinical findings and reduces markers of oxidative stress and inflammation in overweight adults with moderate asthma. Free Radic Biol Med 2007;42:665-74.

29. Simard B, Turcotte H, Marceau P, et al. Asthma and sleep apnea in patients with morbid obesity: outcome after bariatric surgery. Obes Surg 2004;14:1381-8.

30. Sugerman HJ, Sugerman EL, DeMaria EJ, et al. Bariatric surgery for severely obese adolescents. J Gastrointest Surg 2003;7:102-7.

31. Aaron SD, Fergusson D, Dent R, et al. Effect of weight reduction on respiratory function and airway reactivity in obese women. Chest 2004;125:2046-52.

32. Ahroni JH, Montgomery KF, Watkins BM. Laparoscopic adjustable gastric banding: weight loss, co-morbidities, medication usage and quality of life at one year. Obes Surg 2005;15:641-7.

33. Dixon JB, Chapman L, O'Brien P. Marked improvement in asthma after Lap-Band surgery for morbid obesity. Obes Surg 1999;9:385-9

34. Hall JC, Watts JM, O'Brien PE, et al. Gastric surgery for morbid obesity. The Adelaide Study. Ann Surg 1990;211:419-27.

35. Murr MM, Siadati MR, Sarr MG. Results of bariatric surgery for morbid obesity in patients older than 50 years. Obes Surg 1995;5:399-402.

36. Narbro K, Agren G, Jonsson E, et al. Pharmaceutical costs in obese individuals: comparison with a randomly selected population sample and long-term changes after conventional and surgical treatment: the SOS intervention study. Arch Intern Med 2002; 162:2061-9.

37. O'Brien PE, Dixon JB, Brown W, et al. The laparoscopic adjustable gastric band (Lap-Band): a prospective study of medium-term effects on weight, health and quality of life. Obes Surg 2002;12:652-60.

38. Spivak H, Hewitt MF, Onn A, et al. Weight loss and improvement of obesity-related illness in 500 U.S. patients following laparoscopic adjustable gastric banding procedure. Am J Surg 2005;189:27-32.

39. Dhabuwala A, Cannan RJ, Stubbs RS. Improvement in co-morbidities following weight loss from gastric bypass surgery. Obes Surg 2000;10:428-35.

40. National Asthma Council Australia. Asthma Management Handbook 2006 Melbourne, 1997. Available at www.nationalasthma.org.au/cms/index.php lassessed 26 March 2008)

41. Harding SM. Gastroesophageal reflux, asthma, and mechanisms of interaction. Am J Med 2001;111(Suppl 8A):8S-12.

42. Corley DA, Kubo A. Body mass index and gastroesophageal reflux disease: a systematic review and meta-analysis. Am J Gastroenterol 2006;101:2619-28.

43. Jacobson BC, Somers SC, Fuchs CS, et al. Body-mass index and symptoms of gastroesophageal reflux in women. N Engl J Med 2006;354:2340-8.

44. Lagergren J, Bergstrom R, Nyren 0 . No relation between body mass and gastrooesophageal reflux symptoms in a Swedish population based study. Gut 2000; 47:26-9.

45. Tolonen $\mathbf{P}$, Victorzon $M$, Niemi R, et al. Does gastric banding for morbid obesity reduce or increase gastroesophageal reflux? Obes Surg 2006;16:1469-74.
46. Miedema I, Feskens EJM, Heederik D, et al. Dietary determinants of long-term incidence of chronic nonspecific lung disease: The Zutphen Study. Am J Epidemiol 1993;138:37-45

47. Schwartz J, Weiss ST. Dietary factors and their relation to respiratory symptoms: The Second National Health and Nutrition Examination Survey. Am J Epidemiol 1990:132:67-76.

48. Schwartz J, Weiss ST. The relationship of dietary fish intake to level of pulmonary function in the first National Health and Nutrition Survey (NHANES I). Eur Respir $J$ 1994:7:1821-4.

49. Shahar E, Folsom AR, Melnick SL, et al. Dietary n-3 polyunsaturated fatty acids and smoking-related chronic obstructive pulmonary disease. N Engl J Med 1994:331:228-33.

50. Peat JK, Salome CM, Woolcock AJ. Factors associated with bronchial hyperresponsiveness in Australian adults and children. Eur Respir J 1992;5:921-9.

51. Hodge L, Salome CM, Peat JK, et al. Consumption of oily fish and childhood asthma risk. Med J Aust 1996;164:137-40.

52. McFadden ER Jr, Gilbert IA. Asthma. N Engl J Med 1992;327:1928-37.

53. Lee TH, Hoover RL, Williams JD, et al. Effect of dietary enrichment with eicosapentaenoic and docosahexaenoic acids on in vitro neutrophil and monocyte leukotriene generation and neutrophil function. N Engl J Med 1985;312:1217-24.

54. Simopoulos AP. Omega-3 fatty acids in health and disease and in growth and development. Am J Clin Nutr 1991;54:438-63.

55. Oddy WH, de Klerk NH, Kendall GE, et al. Ratio of omega- 6 to omega-3 fatty acids and childhood asthma. J Asthma 2004;41:319-26.

56. Dry J, Vincent D. Effect of a fish oil diet on asthma: Results of a 1-year double-blind study. Int Arch Allergy Appl Immunol 1991;95:156-7.

57. Knapp HR. Omega-3 fatty acids in respiratory diseases: A review. J Am Coll Nutr 1995; 14:18-23.

58. Nagel G, Linseisen J. Dietary intake of fatty acids antioxidants and selected food groups and asthma in adults. Eur J Clin Nutr 2005;59:8-15.

59. Sood A, Ford ES, Camargo CA Jr. Association between leptin and asthma in adults. Thorax 2006;61:300-5.

60. Mai XM, Bottcher MF, Leijon I. Leptin and asthma in overweight children at 12 years of age. Pediatr Allergy Immunol 2004;15:523-30.

61. Shaaban R, Leynaert B, Soussan D, et al. Physical activity and bronchial hyperresponsiveness: European Community Respiratory Health Survey II. Thorax 2007:62:403-10.

62. Plaisance EP, Grandjean PW. Physical activity and high-sensitivity C-reactive protein. Sports Med 2006:36:443-58.

63. Rawson ES, Freedson PS, Osganian SK, et al. Body mass index, but not physical activity, is associated with C-reactive protein. Med Sci Sports Exerc 2003;35:1160-6.

64. National Asthma Education and Prevention Program Expert Panel Report 3 (EPR-3) Guidelines for the Diagnosis and Management of Asthma - Full Report, August 2007. Available at http://www.nhlbi.nih.gov/guidelines/asthma/asthgdln.pdf (accessed 26 March 2008).

65. National Asthma Education and Prevention Program Expert Panel Report: Guidelines for the Diagnosis and Management of Asthma-Update on Selected Topics 2002. http://www.nhlbi.nih.gov/guidelines/asthma/index.htm (accessed 26 March 2008).

66. Krebs JD, Browning LM, McLean NK, et al. Additive benefits of long-chain n-3 polyunsaturated fatty acids and weight-loss in the management of cardiovascular disease risk in overweight hyperinsulinaemic women. Int J Obes (Lond) 2006;30:1535-44.

67. Nettleton JA, Katz R. n-3 long-chain polyunsaturated fatty acids in type 2 diabetes: a review. J Am Diet Assoc 2005;105:428-40.

68. Broughton KS, Johnson CS, Pace BK, et al. Reduced asthma symptoms with n-3 fatty acid ingestion are related to 5 -series leukotriene production. Am J Clin Nutr 1997;65:1011-17

\section{Let us assist you in teaching the next generation}

Figures from all articles on our website can be downloaded as a PowerPoint slide. This feature is ideal for teaching and saves you valuable time. Just click on the image you need and choose the "PowerPoint Slide for Teaching" option. Save the slide to your hard drive and it is ready to go. This innovative function is an important aid to any clinician, and is completely free to subscribers. (Usual copyright conditions apply.) 